\title{
Assessment of Nutrients-Chlorophyll- $a$ Relationship in the Lower Danube River
}

\author{
Mihaela Ilie, Florica Marinescu, Gina Ghita, Ana-Maria Anghel, György Deák, Marius Raischi
}

\begin{abstract}
Distribution and variability of chlorophyll- $a$ were investigated in this study, in relation to nutrient concentrations (total nitrogen-TN, total phosphorus-TP) and hydro-meteorological conditions. The ratio and sum between TN and TP were also studied. Water samples were collected monthly, during September 2012 August 2014, from left and right banks of the Danube River. Regarding the seasonal dynamics of Chl- $a$, the highest concentration was recorded in summer $(49.75 \mu \mathrm{g} / \mathrm{L})$ and the lowest one was observed in winter $(0.59 \mu \mathrm{g} / \mathrm{L})$. The highest Chl- $a$ annual mean concentration was observed in $2013(19.00 \mu \mathrm{g} / \mathrm{L})$, closely linked to minimal discharge of the Danube River $(2500 \mathrm{mc} / \mathrm{s})$ from the monitored period. In case of Chl- $a$ and total phosphorus, cluster analysis assembled the sampling sections in two different clusters considering the location. Pearson correlation coefficient revealed a weakly relationship between chlorophyll $a$ and total nitrogen and no significant correlation between Chl- $a$ and total phosphorus during summer.
\end{abstract}

Keywords-chlorophyll a, cluster analysis, Danube River, nutrients

\section{INTRODUCTION}

Nutrients enrichment is a frequently mentioned cause for biotic deterioration of water bodies, but little is known about nutrients - chlorophyll- $a$ (Chl- $a)$ relationship in lotic environments. One of the most common ecological and environmental problems of water bodies is eutrophication, which diminishes water quality by spurring the excessive growth of algae and increasing suspended organic material [1, 2]. At present, there are more indicators of eutrophication, mainly being the nutrients as total phosphorus and total nitrogen and chlorophyll which is an indicator of phytoplankton biomass [3]. The growth of phytoplankton biomass in large rivers, mainly depends on hydrodynamic conditions, climatic conditions, residence time and light conditions but it is also influenced by the availability and concentration of nutrients $[4,5]$. The levels of nutrients in a water body play an essential role in identifying the level of pollution [6]. The European Water Framework Directive 2000/60/EC (WFD), the most significant and complex legislative instrument in the field of water policy, develops the concept of ecological quality status for the assessment of water quality - based on the physical-chemical, hydromorphologic and biological quality elements.

Mihaela Ilie, Florica Marinescu, Gina Ghita, Ana-Maria Anghel, György Deák and Marius Raischi are with the National Institute for Research and Development in Environmental Protection, Bucharest, 294 Splaiul Independentei, 6th District, 060031, Romania
Within the Danube River basin, phytoplankton assessment is particularly relevant because the Danube River as well as several of the larger tributaries have a great potential to produce large amounts of phytoplankton biomass [1]. In this study we evaluated the level of trophicity by means of the following parameters: total phosphorus, total nitrogen and chlorophyll- $a$ and spatial representation of concentration variation for the investigated parameters was also performed.

\section{STUDIED AREA}

This study investigates the relationships between Chl- $a$, total nitrogen (TN) and total phosphorus (TP) using data from a large range of samples from the Danube River between $\mathrm{Km}$ 347 and Km 182, during September 2012 - August 2014.

Average data on trophic state parameters, total phosphorus (TP), total nitrogen (TN) and chlorophyll- $a$ (Chl- $a$ ) were obtained from the analysis of 560 water samples. Monthly samples were collected from ten sections (Fig. 1), between September 2012 and August 2014, from left and right banks of the Danube River.

The locations of sampling sections are shown in Table 1, and the sections were divided into two sectors: upstream (S1S7) and downstream (S8-S10).

TABLE 1 SAMPLING SiTE LOCATION SITE LOCATION

\begin{tabular}{|c|c|c|c|}
\hline \multirow{2}{*}{ Sections } & \multirow{2}{*}{ River km } & \multicolumn{2}{|c|}{$\begin{array}{c}\text { Geographical coordinates } \\
\text { (latitude, longitude) }\end{array}$} \\
\hline & & Left bank & Right bank \\
\hline \multirow{2}{*}{$\mathrm{S} 1$} & \multirow{2}{*}{ Danube km 348} & $44^{\circ} 10^{\prime} 35.63^{\prime \prime} \mathrm{N}$ & $44^{\circ} 10^{\prime} 18.31^{\prime \prime} \mathrm{N}$ \\
\hline & & $27^{\circ} 32^{\prime} 18.44^{\prime \prime} \mathrm{E}$ & $27^{\circ} 32^{\prime} 33.18^{\prime \prime} \mathrm{E}$ \\
\hline \multirow{2}{*}{$\mathrm{S} 2$} & \multirow{2}{*}{ Bala Branch km 9.4} & $44^{\circ} 12^{\prime} 05.33^{\prime \prime} \mathrm{N}$ & $44^{\circ} 11^{\prime} 59.39^{\prime \prime} \mathrm{N}$ \\
\hline & & $27^{\circ} 34^{\prime} 26.60^{\prime \prime} \mathrm{E}$ & $27^{\circ} 34^{\prime} 39.67^{\prime \prime} \mathrm{E}$ \\
\hline \multirow{2}{*}{ S3 } & \multirow{2}{*}{ Danube km 344.8} & $44^{\circ} 11 ' 39.20^{\prime \prime} \mathrm{N}$ & $44^{\circ} 11^{\prime} 19.92^{\prime \prime N}$ \\
\hline & & $27^{\circ} 34^{\prime} 38.55^{\prime \prime} \mathrm{E}$ & $27^{\circ} 34^{\prime} 56.75^{\prime \prime} \mathrm{E}$ \\
\hline \multirow{2}{*}{$\mathrm{S} 4$} & \multirow{2}{*}{ Borcea Branch km 65} & $44^{\circ} 16^{\prime} 14.93^{\prime \prime} \mathrm{N}$ & $44^{\circ} 16^{\prime} 02.26^{\prime \prime} \mathrm{N}$ \\
\hline & & $27^{\circ} 38^{\prime} 51.90^{\prime \prime} \mathrm{E}$ & $27^{\circ} 39^{\prime} 00.21^{\prime \prime} \mathrm{E}$ \\
\hline \multirow{2}{*}{ S5 } & \multirow{2}{*}{ Danube km 338} & $44^{\circ} 12^{\prime} 22.62^{\prime \prime} \mathrm{N}$ & $44^{\circ} 12^{\prime} 12.62^{\prime \prime} \mathrm{N}$ \\
\hline & & $27^{\circ} 39^{\prime} 11.60^{\prime \prime} \mathrm{E}$ & $27^{\circ} 39^{\prime} 10.87^{\prime \prime} \mathrm{E}$ \\
\hline \multirow{2}{*}{ S6 } & \multirow{2}{*}{ Epurasu Branch km 1.8} & $44^{\circ} 11 ' 25.64^{\prime \prime N}$ & $44^{\circ} 11^{\prime} 18.12^{\prime \prime} \mathrm{N}$ \\
\hline & & $27^{\circ} 41^{\prime} 08.09^{\prime \prime} \mathrm{E}$ & $27^{\circ} 41^{\prime} 10.72 " \mathrm{E}$ \\
\hline \multirow{2}{*}{ S7 } & \multirow{2}{*}{ Danube km 334.3} & $44^{\circ} 11^{\prime} 53.25^{\prime \prime} \mathrm{N}$ & $44^{\circ} 11^{\prime} 37.96^{\prime \prime N}$ \\
\hline & & $27^{\circ} 42^{\prime} 10.45^{\prime \prime} \mathrm{E}$ & $27^{\circ} 42^{\prime} 11.23^{\prime \prime} \mathrm{E}$ \\
\hline \multirow{2}{*}{ S8 } & \multirow{2}{*}{ Caleia Branch km 8.9} & $45^{\circ} 04^{\prime} 56.17^{\prime \prime} \mathrm{N}$ & $45^{\circ} 04^{\prime} 53.16^{\prime \prime N}$ \\
\hline & & $27^{\circ} 54^{\prime} 06.61^{\prime \prime} \mathrm{E}$ & $27^{\circ} 54 ' 21.88^{\prime \prime} \mathrm{E}$ \\
\hline \multirow{2}{*}{ S9 } & \multirow{2}{*}{ Danube km 186.5} & $45^{\circ} 08^{\prime} 39.15^{\prime \prime} \mathrm{N}$ & $45^{\circ} 08^{\prime} 43.19^{\prime \prime} \mathrm{N}$ \\
\hline & & $27^{\circ} 57^{\prime} 43.51^{\prime \prime} \mathrm{E}$ & $27^{\circ} 57 ' 52.69^{\prime \prime} \mathrm{E}$ \\
\hline \multirow{2}{*}{$\mathrm{S} 10$} & \multirow{2}{*}{ Danube km 182.6} & $45^{\circ} 10^{\prime} 19.60^{\prime \prime N}$ & $45^{\circ} 10^{\prime} 21.23^{\prime \prime} \mathrm{N}$ \\
\hline & & $27^{\circ} 56^{\prime} 22.34^{\prime \prime} \mathrm{E}$ & $27^{\circ} 56^{\prime} 46.71 " \mathrm{E}$ \\
\hline
\end{tabular}




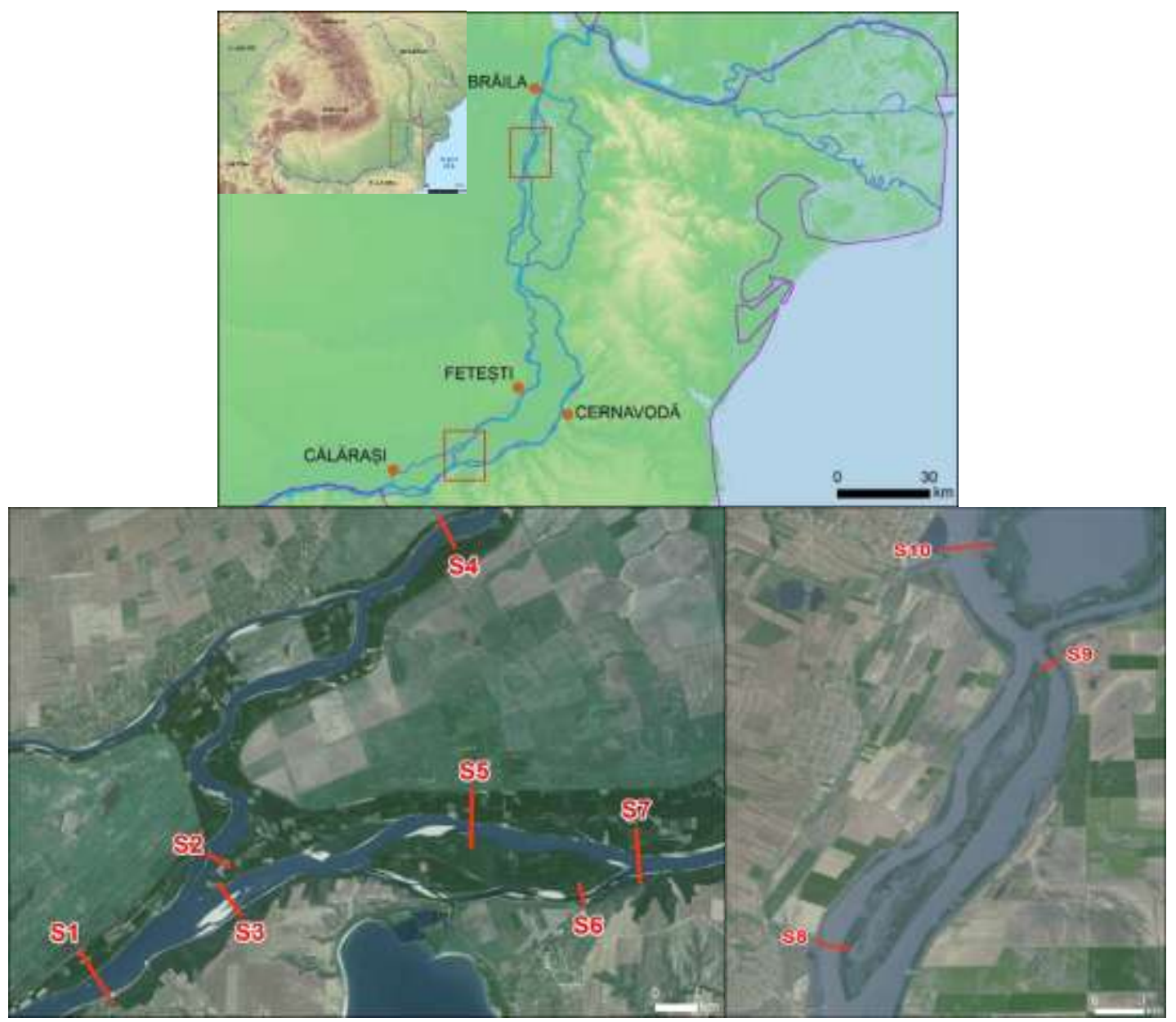

Fig. 1 Sampling sections located along the lower part of Danube River, Romania

Chl- $a$ was extracted using $90 \%$ of alcohol and

\section{III.MATERIALS AND METHOD}

In order to assess the trophic status, water samples were taken monthly from ten sites along the Danube River Km 347 and Km Between 182 during September 2012 - August 2014 for analysis of NT, PT and chlorophyll-a. Sampling, processing and preservation of evidence WAS performed taking into account national and international Standards for determining TN, TP and chlorophyll- $a$. The river flow discharge $(\mathrm{mc} / \mathrm{s})$ of the Danube was measured in several points. Right after sampling, samples were placed in cold storage units, until further analysis in the laboratory.

Environmental and Water No 161/2006 for the Approval of the Norm Concerning the Reference Objectives for the Surface Water Quality Classification (Official Journal of Romania, Part 1, No 511 bis), transposed from European Water Framework Directive 2000/60/EC. The Order 161/2006 establishes five classes of environmental status for the aquatic ecosystems of lakes and rivers type: (I) very good, (II) good, (III) moderate, (IV) poor and (V) bad [7].

\section{RESUlTS AND DISCUSSION}

Generally, nutrient concentrations were relatively high (1.64 $\mathrm{mg} / \mathrm{L}$ average value of $\mathrm{TN}, 0.10 \mathrm{mg} / \mathrm{L}$ average value of spectrophotometrical quantification was performed at 665 and $750 \mathrm{~nm}$. Nutrients (TN and TP) were also determined by spectrophotometrical method at $655 \mathrm{~nm}$ and $880 \mathrm{~nm}$ wavelengths, using the UV-VIS ATI UNICAM, type UV2 equipment.

Data for the studied parameters were analyzed using the descriptive statistics. Pearson correlation coefficient was used to correlate concentration values of TN, TP and Chl- $a$ in the Danube. The cluster analysis was also used to distribute the studied parameters into groups based on similarities/ differences between different groups.

Water quality assessments were performed considering quality guidelines in Romania - Order of the Ministry of $\mathrm{TP}$ ), with maximum values of TN and TP during summer (Fig. 2 and Fig.3). High values of chlorophyll- $a$ concentration recorded in the summertime are associated with the low Danube flow (Fig. 4) as a result of low rainfall and relatively high concentrations of nutrients during this period. The averages of water temperatures was $15.0^{\circ} \mathrm{C}$. The minimum water temperature was $1.1{ }^{\circ} \mathrm{C}$ in December and its maximum value reached $27.2^{\circ} \mathrm{C}$ in July.

The seasonal dynamics of Chl- $a$ : the highest concentration was recorded in summer $\left(49.75 \mu \mathrm{gL}^{-1}\right)$ and the lowest one was observed in winter $\left(0.59 \mu \mathrm{gL}^{-1}\right)$. 


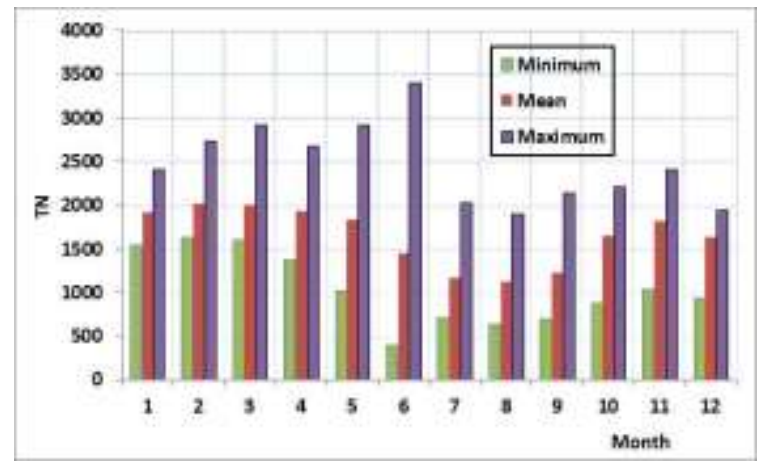

Fig. 2 TN concentration variation

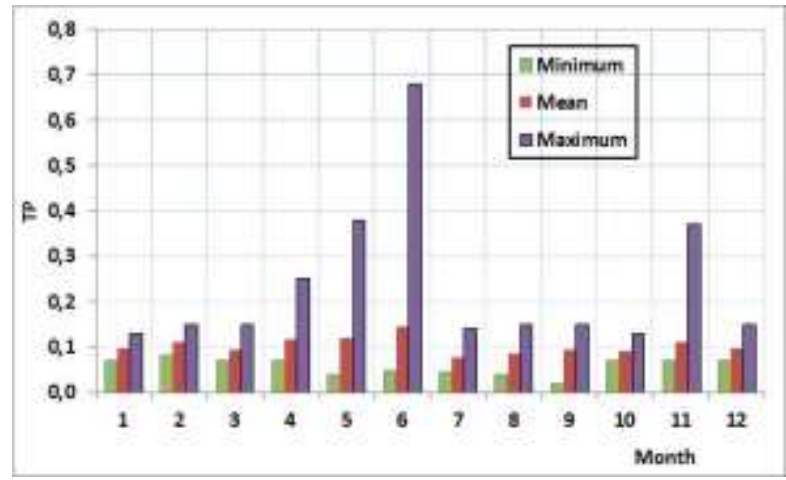

Fig. 3 TP concentration variation

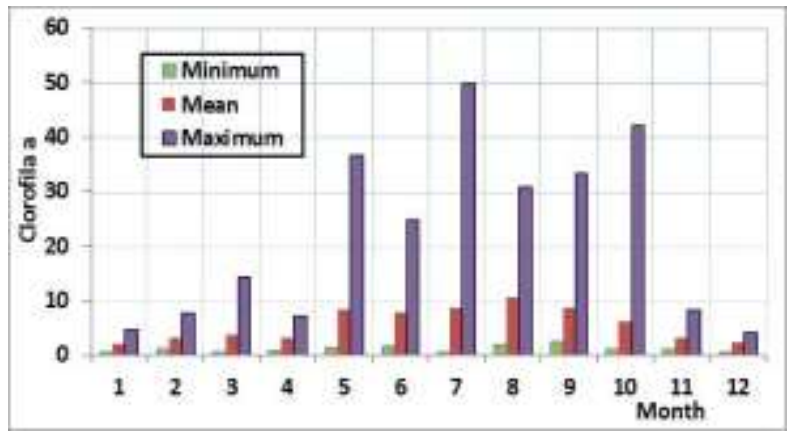

Fig. 4 Chl- $a$ concentration variation

Statistical processing of analytical data and setting up the database to achieve GIS maps is an essential phase of water quality assessment. Statistical analyses were performed using the following software package: Minitab 16 and JMP 9 (SAS).

The ranges, means, standard deviations, and medians of TN, TP and chlorophyll- $a$ during September 2012 - August 2014 are presented in Table 2.
In the area under study, the following concentration ranges were registered for the studied parameters: $0.390-3.390 \mathrm{mg} / \mathrm{L}$ for TN; 0.02-0.68 mg / L for TP; 0.59-49.75 mg / L for Chl- $a$. Similar range of nutrients and chlorophyll- $a$ concentrations in water samples from the Danube was reported through the results obtained in the Joint Danube Survey Expedition 3 [8].

TABLE II

SUMMARY DESCRIPTIVE STATISTICS FOR TN, TP AND Chl- $a$ DURING THE PERIOD 2012-2014

\begin{tabular}{|c|c|c|c|c|c|c|c|c|c|}
\hline Variable & Season & Count & Mean & StDev & CoefVar & Median & Minimum & Maximum & $\begin{array}{c}\text { CMA }^{*} \\
\text { Order 161/2006; } \\
\text { WFD Limits } \\
{[7,9]}\end{array}$ \\
\hline \multirow[t]{4}{*}{ TN } & fall & 80 & 1.7311 & 300.2 & 17.34 & 1.720 & 0.880 & 2.400 & \multirow[t]{4}{*}{7.0} \\
\hline & spring & 100 & 1.8688 & 329.6 & 17.64 & 1.840 & 1.009 & 2.910 & \\
\hline & summer & 280 & 1.2478 & 473.3 & 37.93 & 1.130 & 0.390 & 3.390 & \\
\hline & winter & 200 & 1.9114 & 282.4 & 14.77 & 1.900 & 0.930 & 2.910 & \\
\hline \multirow[t]{4}{*}{$\mathrm{TP}$} & fall & 80 & 0.1014 & 35.21 & 34.73 & 0.095 & 0.070 & 0.370 & \multirow[t]{4}{*}{0.4} \\
\hline & spring & 100 & 0.1191 & 57.93 & 48.64 & 0.110 & 0.039 & 0.380 & \\
\hline & summer & 280 & 0.1024 & 74.52 & 72.77 & 0.090 & 0.020 & 0.680 & \\
\hline & winter & 200 & 0.0988 & 18.03 & 18.25 & 0.100 & 0.070 & 0.150 & \\
\hline \multirow[t]{4}{*}{ Chl-a } & fall & 80 & 4,689 & 4,991 & 106,44 & 3,55 & 1,18 & 42,1 & \multirow[t]{4}{*}{50} \\
\hline & spring & 100 & 6,308 & 5,722 & 90,71 & 4,219 & 0,89 & 36,72 & \\
\hline & summer & 280 & 8,889 & 5,869 & 66,03 & 7,7 & 0,59 & 49,75 & \\
\hline & winter & 200 & 3,011 & 2,383 & 79,14 & 2,37 & 0,59 & 14,22 & \\
\hline
\end{tabular}

Pearson correlation analysis was applied in order to correlate the studied parameters (tab. 3). 
TABLE III

PEARSON CORRELATION ( $r$ VALUE) OF THE TN, TP AND Chl $-a$ CONCENTRATION IN THE DANUBE SURFACE WATER

\begin{tabular}{ccccc}
\hline Season & & TN & TP & Chl-a \\
\hline 2012-2014 & TN & 1 & & \\
& TP & 0.372 & 1 & \\
\multirow{5}{*}{ spring } & Chl-a & -0.186 & -0.02 & 1 \\
& TN & 1 & & \\
& TP & 0.071 & 1 & \\
summer & Chl-a & -0.184 & 0.355 & 1 \\
& TN & 1 & & \\
& TP & 0.596 & 1 & 1 \\
\multirow{5}{*}{ fall } & Chl-a & 0.215 & -0.128 & \\
& TN & 1 & & \\
& TP & 0.201 & 1 & \\
\multirow{5}{*}{ winter } & Chl-a & 0.145 & -0.09 & 1 \\
& TN & 1 & & \\
& TP & 0.364 & 1 & \\
& Chl-a & -0.048 & -0.174 & 1 \\
\hline
\end{tabular}
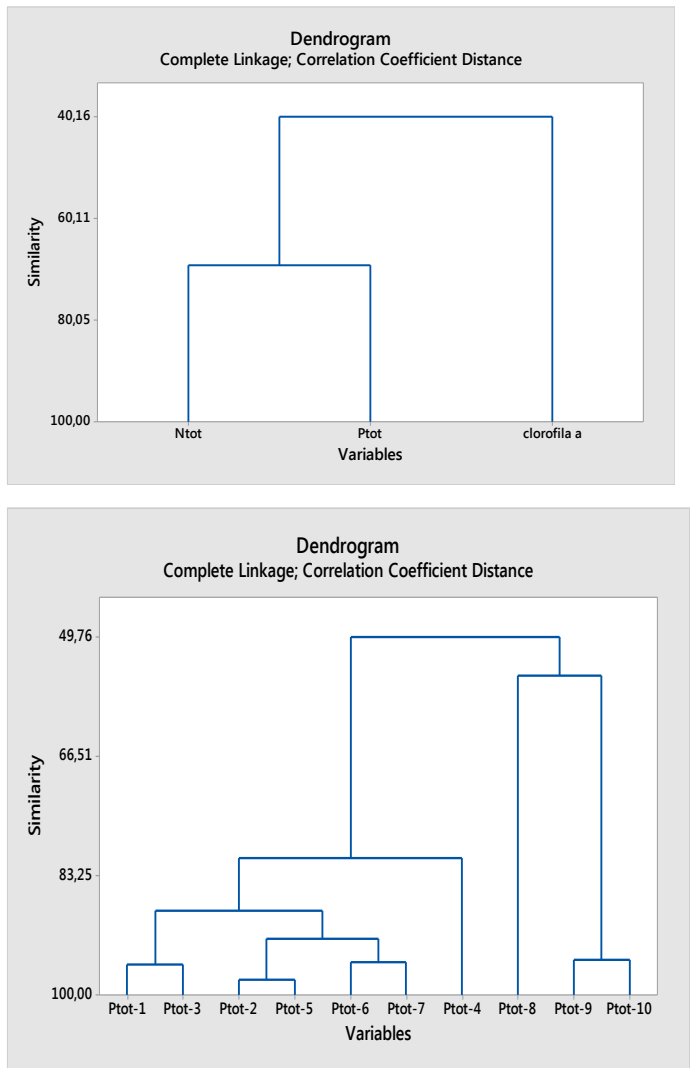

In the last decades, the clustering techniques have often been applied to a wide variety of research issues [10, 11, 12]. Cluster analysis: in case of Chl- $a$ - TP the sampling sections were assembled in two different clusters considering the location.

Pearson's $r$ coefficient and dendogram correlation for TN, TP and chlorophyll $a$ concentration in the Danube water showed:

- a weak correlation between Chl- $a$ and TP $(\mathrm{r}=0.355)$ in spring and TP-TN in fall $(\mathrm{r}=0.201)$ and winter $(\mathrm{r}=0.364)$;

- a moderate correlation between TP-TN $(\mathrm{r}=0.596)$ and a weak relationship between Chl- $a$ and TP $(\mathrm{r}=0,215)$ during summer

The highest Chl- $a$ annual mean concentration was observed in $2013\left(19.00 \mu \mathrm{gL}^{-1}\right)$, closely linked to minimal discharge of the Danube River $(2500 \mathrm{mc} / \mathrm{s})$ from the monitored period.

Pearson's $r$ coefficient revealed a weak relationship between TP and TN ( $\mathrm{r}=0.372)$ and no correlation between Chl- $a-\mathrm{TN}$ and Chl- $a$ - TP for the entire monitoring period.

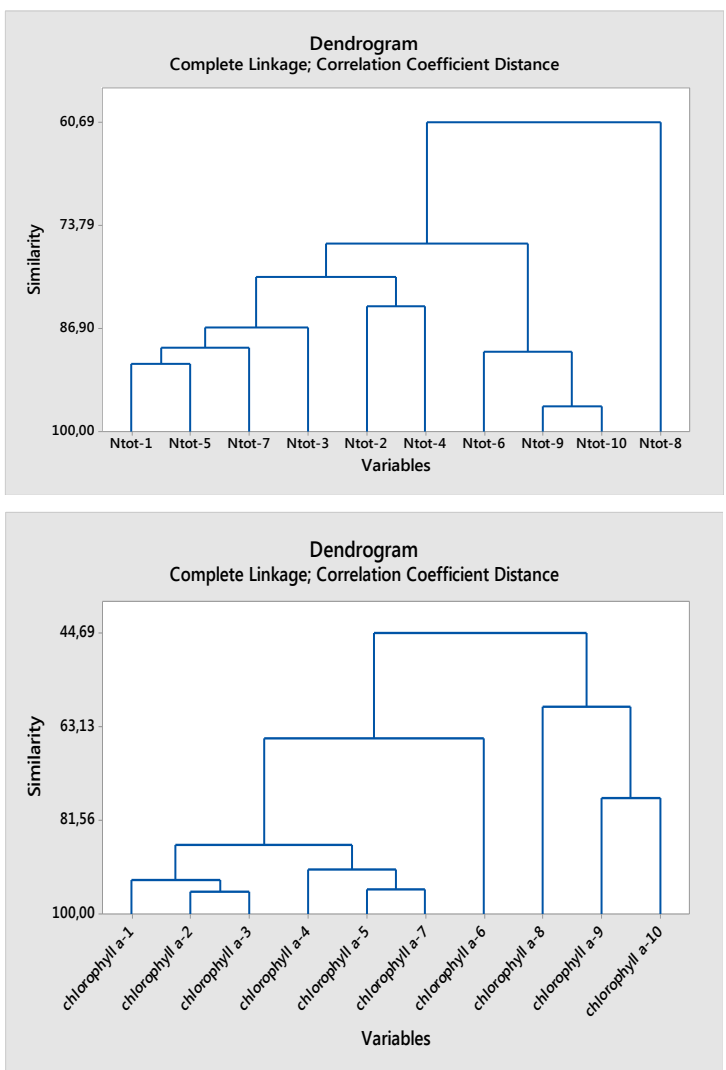

Fig. 5 Dendrograms of the water sampling sections from the Danube River

Spatial distribution of NT, TP and Chl-a in water is important to assess the variation of nutrient quantities due to the influence of human activities [13], hydrological conditions, morphodynamics [14] and nutrient retention.

The GIS mapping technique was involved to create spatial distribution maps of TN, TP and Chl- $a$ in water samples from the Danube River as well as the Danube flow variation during
September 2012 - August 2014. The software used for mapping and spatial analysis was ArcView 9.3. These operations consist of interpolation of all values and developing spatial images (map) to highlight the values (value classes) by cartographic ways. Spatial distribution of TN, TP and Chl- $a$ in water along the Danube River between Km 347 and Km 182 
as well as the Danube flow variation are shown in the following figures.

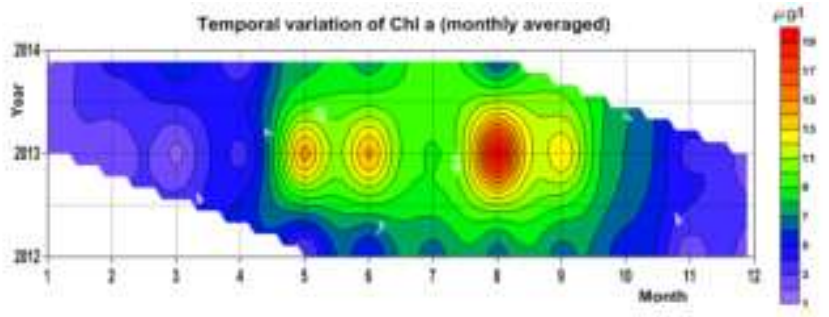

Fig. 6 Temporal variation of Chl-a in the Lower Danube River (monthly averaged in September 2012 - August 2014)

Distribution of Chl- $a$ shows high temporal and spatial variations (Fig 6), and the main factors controlling its distribution during summer, were $\mathrm{TN}$ and $\mathrm{TP}$ (Fig.7) availability and the low Danube flow due to low rainfall in summer. High values of chlorophyll concentration recorded in the summertime are associated with the low Danube flow (Fig.8) as a result of low rainfall and relatively high concentrations of nutrients during this period.

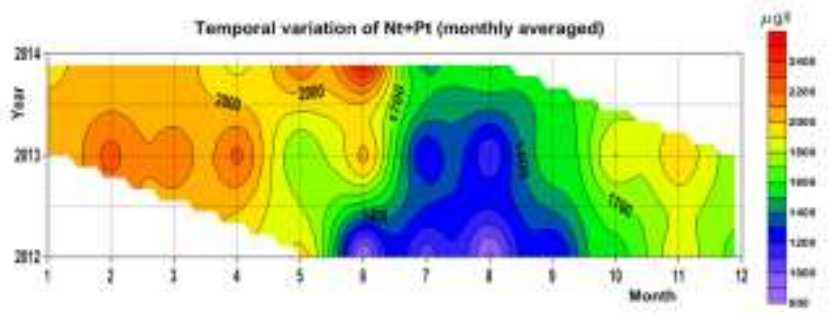

Fig. 7 Temporal variation of the TN+TP in the Lower Danube River (monthly averaged during September 2012 - August 2014)

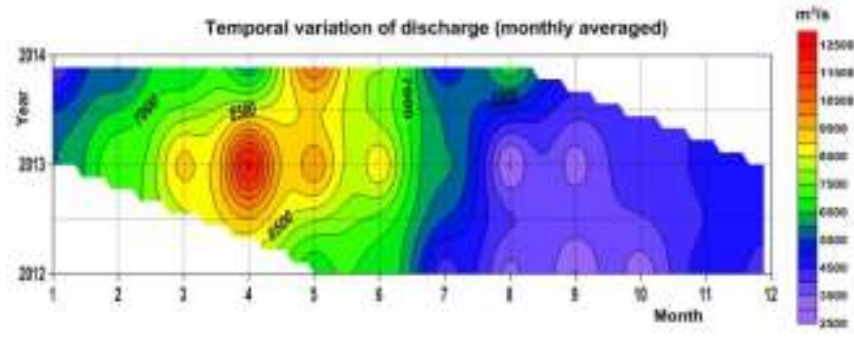

Fig. 8 Temporal variation of the Danube River discharge (monthly averaged during September 2012 - August 2014)

\section{CONCLUSION}

Eutrophication of surface waters is a consequence of enriching water with nutrients and leads to overgrowth of algae and other aquatic plants. This study was conducted to assess changes in concentrations of nutrients and Chl- $a$ by determining their concentration and spatial distribution in the Danube River, between $\mathrm{Km} 347$ and $\mathrm{Km}$ 182, during September 2012 - August 2014. It reveals that in terms of Chl- $a$, there are significant seasonal variations, with maximum concentrations reached in the summertime, when biological activity is most intense, being strongly influenced by weather conditions and anthropogenic pressures.

\section{ACKNOWLEDGMENT}

It was possible for these results to be obtained, thanks to the research conducted by National Institute for Research and Development in Environmental Protection in the development of the project entitled: "Monitoring the environmental impact of works regarding the improving of the navigation conditions on the Danube River between Calarasi and Braila, km 375-175" financed by National and European funds (2011-2017).

\section{REFERENCES}

[1] T. Long, L. Wu, G. Meng, W. Guo, "Numerical simulation for impacts of hydrodynamic conditions on algae growth in Chongqing Section of Jialing River", Ecological Modelling, vol. 222, pp. 112-119, 2011 https://doi.org/10.1016/j.ecolmodel.2010.09.028

[2] M. Strokal, C. Kroeze, "Nitrogen and phosphorus inputs to the Black Sea in 1970-2050". Regional Environmental Change, vol. 1, pp. 179192,2013

https://doi.org/10.1007/s10113-012-0328-z

[3] A.M. Gollop, A.J. Gilbert, L.D. Mee, J.E. Vermaat, Y. Artioli, C. Humborg, F. Wulff, "How well do ecosystem indicators communicate the effects of anthropogenic eutrophication?", Estuarine, Coastal and Shelf Science, vol. 82, pp. 583-596, 2009 https://doi.org/10.1016/j.ecss.2009.02.017

[4] D.J.J. Tysmans, A.J. Löhr, C. Kroezea, W.P.M.F. Ivens, Jikke van Wijnen, "Spatial and temporal variability of nutrient retention in river basins: A global inventory", Ecological Indicators, vol. 34, pp. 607-615, 2013 https://doi.org/10.1016/j.ecolind.2013.06.022

[5] C. Humborg, V. Ittekkot, A. Cociasu, B. von Bodungen, "Effect of Danube river dam on Black Sea biochemistry and ecosystem structure", Nature, vol. 386, pp. 385-388, 1997 https://doi.org/10.1038/386385a0

[6] T.A. Ali, M. Martula, S.Atabay, "GIS-based study on the susceptibility of Dubai Creek (UAE) to eutrophication", Polish Journal of Environmental Studies, vol. 25, no. 6, pp. 2275-2282, 2016 https://doi.org/10.15244/pjoes/63659

[7] ***Order of the Ministry of Environmental and Water No 161/2006 for the Approval of the Norm Concerning the Reference Objectives for the Surface Water Quality Classification, Official Monitor of Romania, Part 1, No 511 bis, 2006

[8] *** Joint Danube Survey 3 (JDS3) Final Report, ICPDR, https://www.icpdr.org/main/activities-projects/jds3, 2015

[9] ***WFD, Directive 2000/60/EC of the European Parliament and of the Council of 23 October 2000 Establishing a Framework for Community Action in the Field of Water Policy, 2000

[10] Z. Yuan, S. Taoran, Z. Yan, Y. Tao, "Spatial distribution and risk assessment of heavy metals in sediments from a hypertrophic plateau lake Dianchi, China”. Environmental Monitoring and Assessment, vol. 186, pp. 1219-1234, 2014 https://doi.org/10.1007/s10661-013-3451-5

[11] J. Ren, Z. Shang, L. Tao, X. Wang, "Multivariate analysis and heavy metals pollution evaluation in Yellow River surface sediments", Polish Journal of Environmental Studies, vol. 24, no. 3, pp. 1041-1048, 2015

[12] S.K. Sundaray, B.B. Nayak, S. Lin, D. Bhatta, "Geochemical speciation and risk assessment of heavymetals in the river estuarine sediments-a case study: Mahanadi basin, India", Journal of Hazardous Materials, vol. 186, pp. 1837-1846, 2011 https://doi.org/10.1016/j.jhazmat.2010.12.081

[13] H. Blaas, C. Kroeze, "Excessive nitrogen and phosphorus in European rivers: 2000-2050", Ecological Indicators, vol. 67, pp. 328-337, 2016 https://doi.org/10.1016/j.ecolind.2016.03.004

[14] J. F. Lopes, M.A. Almeida, M.A. Cunhaa, "Modelling the ecological patterns of a temperate lagoon in a very wet spring season", Ecological Modelling, vol. 221, pp. 2302-2322, 2010 https://doi.org/10.1016/j.ecolmodel.2010.06.009 
M. Ilie was born in 1969. She graduated in technology of organic substances and obtained her Engineer Bachelor's degree from University Politehnica of Bucharest - Faculty of Applied Chemistry and Materials Science in 1996. She completed her Ph.D. degree in chemistry from University Politehnica of Bucharest - Faculty of Energetics in 2009. She is currently working as a senior researcher III at the Laboratories Department from National Institute of Research and Development for Environment Protection - INCDPM Bucharest. She has experience in environmental field: scientific research activity; wastewater characterization and treatment solutions; landfilling solutions, identification, evaluation and rehabilitation of contaminated sites, waste recovery and recycling technologies, hazardous waste testing; analysis of leachates and wastewater; risk evaluation; municipal and industrial wastewater. She has published many articles in international journals and research papers presented at international/national conferences.

F. Marinescu was born in 1970. She graduated in biology and obtained her Bachelor's degree from University of Bucharest, Faculty of Biology in 1994 She obtained her Master of Science Diploma from University of Bucharest, Faculty of Biology in 1995. She completed her Ph.D. degree in biology from University of Bucharest, Faculty of Biology in 2013. She is currently working as a senior researcher III at the Environmental Quality Control Department from National Institute of Research and Development for Environment Protection - INCDPM Bucharest, has a 22-year experience in environmental microbiology/biology and is a member of the Technical National Committee 323 - Environmental Management. Her research activity is related to the study physiological groups of bacteria involved in biogeochemical cycles of nitrogen, sulphur and carbon and has a consolidated experience in microbiology methods for isolation and identification of microorganisms from water, soil/sediments/sludge and indoor air. She has published many articles in international journals and research papers presented at international/national conferences.

G. Ghiță was born in 1967. She graduated in technology of organic substances and obtained her Engineer Bachelor's degree from University Politehnica of Bucharest - Faculty of Applied Chemistry and Materials Science in 1991. She completed her Ph.D. degree in chemistry from University Politehnica of Bucharest - Faculty of Energetics in 2009. She is currently working as a senior researcher II at the Environmental Quality Control Department from National Institute of Research and Development for Environment Protection - INCDPM Bucharest and has 25-years' experience in environmental protection field who conducted as coordinator/expert in many national and international research projects. Her research studies are focus especially on chemical analytical characterization of wastewater, soil, sediment, waste/leachates and on the development of the necessary analytical methodology, specially applied to environmental problems. She has published many articles in international journals and research papers presented at international/national conferences.

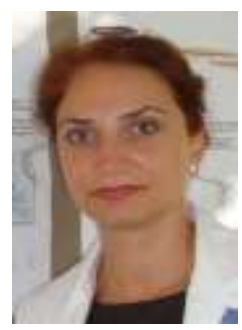

A.M. Anghel was born in 1981. She graduated in protection and environmental engineering in the chemical and petrochemical industry and obtain her Engineer Bachelor's degree in 2005, also obtained her dissertation

in the field of applied chemistry and of electrochemistry in 2007 from University Politehnica of Bucharest -Faculty of

Applied Chemistry and Materials Science. She graduated in economics from the University Spiru Haret - Faculty of Marketing and International Economic Affairs in 2010. She completed her Ph.D. degree in chemistry from University Politehnica of Bucharest - Faculty of Applied Chemistry and Materials Science in 2016. She is currently working as a senior researcher III at the Waste Management Department from National Institute of Research and Development for Environment Protection - INCDPM Bucharest. She has over 10 years' experience in the institute with responsibilities in activities of scientific research in the field of environmental protection: methods of physical-chemical analysis (including heavy metals from water and soil samples), laboratory experiments (water treatment techniques), processing and interpretation of the data obtained, as well as research studies on environmental quality monitoring and control. She has published over 20 articles of which 12 are in international journals and many research papers presented at international/national conferences.

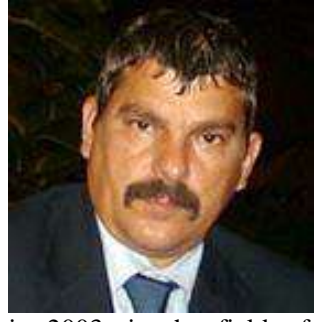

Deák Gy. was born in 1966. He graduated in petrochemical, salt, mining and environmental technology, radioactive, petroleum technology and obtained his Engineer Bachelor's degree from Technical University of Petroşani in 1993. He completed his Ph.D. degree in Engineer Sciences from University of Petroşani

in 2003, in the field of numerical simulation and monitoring systems, preventing ecological disasters. He is currently member in the following Professional Societies: Member in the Balkan Environmental Association, Member in Ministry Board for emergency situations within the Ministry of Environment and Forests, Member in Working Group 1 Air/Air quality, Atmosphere protection and climate changes, National Agency for Environmental Protection, Member in Working Group 6- Ecological Education, Sustainable Development and Life's quality, National Agency for Environmental Protection. He is also a current Member in the Scientific Council of the Danube Delta Biosphere Reserve and Member in the Scientific Council of the National Sanitary Veterinary and Food Safety Authority. Now he is working as General Director at National Institute of Research and Development for Environment Protection - INCDPM Bucharest. He is the coordinator of the Institute's environmental departments, doing research and development in the field of environmental engineering and monitoring, developing strategies and environmental programs. He is also doing the management and the coordination of national/international reseach projects, developing preventive solutions regarding environmental protection issues. He has 7 Golden Medals for contribution to innovation at a mobile station to monitor the ichthyofauna, especially research tools and techniques for sturgeons: Gold Medal - International Invention Innovation Competition in Canada, iCAN , 2016, DKTB - ihtyofauna monitoring system, especially of the sturgeon through the teledection with ultrasonic tag in different hydrological conditions and Gold medal - International Exhibition of Inventions GENEVA, 2016 for DKMR-01T mobile station to monitor through remote sensing, the ichthyofauna, especially sturgeons with ultrasonic tag in difficult hydrological conditions. He was involved in more than 50 national/ international projects, for over 20 of them as project manager and he made sure that, each of his projects he managed met the highest standards for environmental protection. He is the author of over 150 scientific papers and communications, over 60 of them as first author. Also, he is the author of 8 published books, 6 of them as first author.

M. Raischi is specialized in bathymetric measurements and primary data processing, coordinating field teams in the past 5 years. He has several inventions regarding the monitoring and alarm systems. Mr. Raischi has experience in the field of environmental protection, gained in over 55 studies/research projects. Additionally, he has 17 scientific papers (author/coauthor) and 2 specialized books in the field of research-developmentinnovation. 